\title{
Variability of Infiltration within Large Runoff Plots on Rangelands
}

\author{
MICHELINE DEVAURS AND GERALD F. GIFFORD
}

\begin{abstract}
In this study we investigated the variability of infiltration on native rangeland sites. A rainfall simulator was used to collect data on runoff from small $\left(0.37 \mathrm{~m}^{2}\right)$ plots located within large plot boundaries $\left(32.5 \mathrm{~m}^{2}\right)$. Three range sites were sampled and data were collected from unfenced, fenced, and rototilled conditions on each site. In addition data were collected on vegetation, antecedent moisture, bulk density, soil texture, and organic matter as possible explanations for variations in hydrologic response on small and large plots. The field study demonstrated large variability in measured infiltration and soil physical properties on relatively uniform rangeland sites, suggesting that inherent variability patterns need to be examined to provide appropriate confidence intervals for single parameter values that may be applied to larger areas. No set of factors consistently explained the observed variability within large plots.
\end{abstract}

Historically it has been assumed that watersheds are homogeneous. The only data collected were streamflow measurements, which were assumed to integrate hydrologic processes on an entire watershed. Use of rainfall simulators made it possible to assess the impacts of management practices on specific parts of a watershed. That capability led to an emphasis upon characterizing the spatial variability of hydrologic properties to eventually link point and areal measurements.

For simplicity, many hydrologic models still assume that a watershed is homogeneous. Such models ignore the spatial variability of hydrologic properties and lump watershed characteristics as areal averages. However, numerous recent investigations of hydrologic responses (Achouri 1982, Blackburn 1975, Grah 1983, Gifford 1976, Springer and Gifford 1980, Lyford and Qashu 1969, Merzougui 1982, Murabayashi and Fok 1979, Sharma et al. 1980, Rogowski 1980, Tricker 1981, Vieira et al. 1981) have illustrated great spatial variability of hydrologic properties within short distances.

To estimate the effect of spatial variability of infiltration on hydrologic models' assumptions of homogeneous sites or watersheds, areal loss rates must be contrasted with point infiltration rates. Three theoretical explanations of this functioning of natural watersheds have been proposed. Hawkins (1981) submits that watersheds act as a collection of runoff elements, each with independent, uniform hydrologic characteristics. Computer simulation has been used by Smith and Hebbert (1979) and Cundy (1982) to investigate the effects of spatial variability on plot and hillslope performance. Smith and Hebbert developed a model that considered only the spatial variability of rainfall excess. The Cundy model considers variability in soil properties, initial moisture, and rainfall intensity, and routes rainfall excess to downslope using the kinematic wave technique.

Authors are graduate research assistant and professor and chairman, Watershed Science Unit, Range Science Department, Utah State University, UMC 52, Logan 84322. Gifford's current address is Dept. of Range, Wildlife, and Forestry, University of Nevada, Reno 89512. Ms. Devaurs is currently with Los Alamos National Lab, Los Alamos, NM 87545.

This project was supported through the Northwest Watershed Research Center, USDA, ARS, Boise, Ida., and the Utah Agricultural Experiment Station, Projects 749 and 771 . Tech. Pap. 2877, Utah Agricultural Experiment Station, Logan 84322

Manuscript accepted February $7,1984$.
These models implicitly transfer point infiltration properties to a watershed-wide application. They are significant developments, yet they are computer simulations and not adequately field validated. In this field study, we evaluated the variability of infiltration characteristics and soil properties on small $(0.61 \mathrm{~m} \times 0.61 \mathrm{~m})$ runoff plots within large $(3.05 \mathrm{~m} \times 10.67 \mathrm{~m})$ runoff plots on "homogeneous" semiarid rangeland sites.

\section{Site Descriptions}

\section{Study Area}

The field study was conducted during summer, 1981, on rangeland sites located on the Reynolds Creek Experimental Watershed near Boise, Ida. The watershed soils, geology, vegetation, and land use are representative of plateau and foothill grazing areas of the Northwest (Stephenson 1977). Elevations range from about 1,097 $\mathrm{m}$ to $2,225 \mathrm{~m}$. The climate of the watershed ranges from arid to temperate, with annual precipitation varying from $25 \mathrm{~cm}$ at the lower elevations to $127 \mathrm{~cm}$ at the higher elevations. Nearly $75 \%$ of the annual runoff is from snowmelt; however, flash runoffs from smaller areas do occur following intense summer rain storms. Three sites on the Reynolds Creek Experimental Watershed (referred to as Flats, Nancy, and Lower Sheep) were selected for this study. These sites are described in Table 1.

\section{Plot Preparation}

Rainfall simulator plots were located on 3 sites in unfenced, fenced, and tilled conditions. Average large plot slopes were 3, 6, and $9 \%$ on the Flats, Nancy, and Lower Sheep sites, respectively (with the exception of one tilled plot on the Flats site with a $9 \%$ slope); see Table 2. Tilled plots were tilled up and down-slope to approach a fallow condition approximately one week prior to rainfall simulation. They were restored to the original bulk density $(1.1-1.4 \mathrm{~g} / \mathrm{cc}$ ) by natural settling and trampling (walking on the plot) before simulator runs. Fenced sites have been protected from grazing by domestic livestock since 1971. Unfenced sites are grazed both by domestic livestock and wildlife, but exact stocking rates, season, and duration of use data are not available. Generalized grazing allotment data are available from local Bureau of Land Management offices, but the applicability of these data to specific locations on the watershed are limited.

\section{Vegetal Cover}

The 3 sites are typical of sagebrush-grass communities found on the Reynolds Creek Experimental Watershed. The vegetation at the Flats site is chiefly shadscale (Atriplex confertifolia) but includes minor amounts of big sagebrush (Artemisia tridentata), clasping pepperweed (Lepidium perfoliatum), cheatgrass (Bromus tectorum), squirrel tail (Sitanion hystrix), bluegrass (Poa spp.), and moss. At the Nancy site, the dominant species are big sagebrush, little-leaf horsebrush (Tetradymia glabrata), squirrel tail, bluegrass, and moss. Low sagebrush (Artemisia arbuscula) dominates on the Lower Sheep site. The diverse grass and forb understory includes mainly low pussytoes (Antennaria dimorpha), locoweed (Astragalus spp.), bluegrass, and squirrel tail. 
Table 1. Site characteristics on Reynolds Creek watershed near Boise, Idaho.

\begin{tabular}{lcccc}
\hline Site & $\begin{array}{c}\text { Elevation } \\
(\mathrm{m})\end{array}$ & $\begin{array}{c}\text { Annual precipitation } \\
(\mathrm{cm})\end{array}$ & Soil series & Soil description \\
\hline Flats & 1219 & 25 & Nannyton & $\begin{array}{c}\text { Fine loamy, mixed mesic typic } \\
\text { haplargids } \\
\text { Nancy }\end{array}$ \\
Lower sheep & 1402 & 33 & Glasgow & $\begin{array}{c}\text { Fine, montmorillonitic, mesic xerollic } \\
\text { durargid }\end{array}$ \\
& 1646 & 36 & Harmehl & $\begin{array}{c}\text { Fine, montmorillonitic, frigid pachi } \\
\text { argixeroll }\end{array}$ \\
\hline
\end{tabular}

Table 2. Large plot characteristics for each site.

\begin{tabular}{|c|c|c|c|c|c|c|}
\hline Site condition & $\begin{array}{c}\text { Slope } \\
(\%)\end{array}$ & $\begin{array}{l}\text { Rainfall rate } \\
\text { on small plots } \\
(\mathrm{cm} / \mathrm{hr})\end{array}$ & $\begin{array}{l}\text { Total number } \\
\text { of small } \\
\text { plots }\end{array}$ & $\begin{array}{l}\text { Number of small } \\
\text { plots where run- } \\
\text { off occurred }\end{array}$ & $\begin{array}{c}\text { Number of small plots where infil- } \\
\text { tration rate exceeded rainfall } \\
\text { rate for duration of } 30 \text {-minute } \\
\text { run }\end{array}$ & $\begin{array}{l}\text { Mean final } 30- \\
\text { minute infiltra- } \\
\text { tion rate }(\mathrm{cm} / \mathrm{hr})^{1}\end{array}$ \\
\hline Flats unfenced & 3 & 6.35 & 20 & 19 & 1 & $2.5 \pm 1.0$ \\
\hline Flats fenced & 3 & 6.35 & 20 & 15 & 5 & $4.0 \pm 1.0$ \\
\hline Flats tilled & 9 & 6.35 & 10 & 10 & 0 & $1.7 \pm 0.2$ \\
\hline Flats tilled & 3 & 6.35 & 10 & 10 & 0 & $1.3 \pm 0.3$ \\
\hline Flats tilled & 3 & 12.7 & 10 & 10 & 0 & $1.3 \pm 0.6$ \\
\hline Nancy unfenced & 6 & 12.7 & 20 & 19 & 1 & $5.4 \pm 2.3$ \\
\hline Nancy fenced & 6 & 12.7 & 20 & 19 & 1 & $7.2 \pm 3.0$ \\
\hline Nancy tilled & 6 & 12.7 & 10 & 10 & 0 & $2.3 \pm 0.7$ \\
\hline Lower Sheep unfenced & 9 & 12.7 & 20 & 19 & 1 & $7.6 \pm 2.3$ \\
\hline Lower Sheep fenced & 9 & 12.7 & 20 & 15 & 5 & $9.6 \pm 1.2$ \\
\hline Lower Sheep tilled & 9 & 12.7 & 10 & 10 & 0 & $2.3 \pm 0.5$ \\
\hline
\end{tabular}

'Values in this column are reported as mean \pm standard deviation; small plot data (only plots where runoff occurred).

Table 3. Regression models for three sites.

\begin{tabular}{|c|c|c|c|c|c|}
\hline Site & Condition & $\begin{array}{c}\text { Slope } \\
(\%)\end{array}$ & Model & $\begin{array}{c}\mathrm{R}^{2} \\
(\%)\end{array}$ & $\begin{array}{l}\text { Standard error of } \\
\text { regression } \\
(\mathrm{cm} / \mathrm{hr})\end{array}$ \\
\hline Flats & unfenced & 3 & $\mathrm{Y}=13.08-.036 \mathrm{X}_{8}$ & 47.55 & 0.806 \\
\hline Flats & fenced & 3 & $\mathrm{Y}=-3.24+0.152 \mathrm{X}_{6}+0.106 \mathrm{X}_{7}+0.502 \mathrm{X}_{8}-3.99 \mathrm{X}_{11}$ & 95.0 & 0.276 \\
\hline Nancy & unfenced & 6 & $\mathrm{Y}=1.437+1.476 \mathrm{X}_{12}$ & 58.66 & 1.570 \\
\hline Nancy & fenced & 6 & $Y=-4.104+0.108 X_{7}+0.18 X_{13}$ & 68.17 & 1.858 \\
\hline Lower Sheep & unfenced & 9 & $\begin{aligned} \mathrm{Y}= & 11.56-11.56 \mathrm{X}_{1}+0.468 \mathrm{X}_{2}-.072 \mathrm{X}_{3}+ \\
& 0.288 \mathrm{X}_{4}+.036 \mathrm{X}_{5}-.216 \mathrm{X}_{6}+0.180 \mathrm{X}_{7}\end{aligned}$ & 92.04 & 0.8676 \\
\hline Lower Sheep & fenced & 9 & $Y=0.282+0.396 X_{2}+0.036 X_{4}-0.072 X_{5}+.324 X_{6}$ & 95.79 & 0.3528 \\
\hline
\end{tabular}

In all of the above equations, $Y=$ final 30 -minute infiltration rate $(\mathrm{cm} / \mathrm{hr})$ and $X_{1}=$ bulk density of $7.62 \mathrm{~cm}$ soil sample $\left(\mathrm{g} / \mathrm{cm}^{3}\right) ; X_{2}=$ organic matter of $7.62 \mathrm{~cm}$ soil sample $(\%) ; X_{3}$ $=$ sand in $7.62 \mathrm{~cm}$ soil sample $(\%) ; X_{4}=$ sand + silt in $7.62 \mathrm{~cm}$ soil sample $(\%) ; X_{5}=$ total live overstory of shrubs, grasses, and forbs $(\%) ; X_{6}=$ bare ground $(\%) ; X_{7}=$ litter cover $(\%)$; $\mathrm{X}_{8}=$ shrub canopy $(\%) ; X_{11}=$ bulk density of $2.54 \mathrm{~cm}$ soil sample $\left(\mathrm{g} / \mathrm{cm}^{3}\right) ; \mathrm{X}_{12}=$ organic matter in $2.54 \mathrm{~cm}$ soil sample $(\%) ; X_{13}=$ sand in $2.54 \mathrm{~cm}$ soil sample $(\%)$.

Table 4. Necessary sample size to estimate true population mean.

\begin{tabular}{|c|c|c|c|c|c|c|c|}
\hline \multirow[b]{2}{*}{ Site } & \multirow[b]{2}{*}{ Condition } & \multirow{2}{*}{$\begin{array}{c}\text { Slope } \\
(\%)\end{array}$} & \multirow{2}{*}{$\begin{array}{c}\text { Rainfall } \\
\text { rate on small } \\
(\mathrm{cm} / \mathrm{hr})\end{array}$} & \multicolumn{2}{|c|}{$\begin{array}{c}\text { Sample size necessary for } \bar{x} \\
\text { (time to ponding) within } \\
\text { two minutes of } \mu \text { with } \\
\text { confidence }\end{array}$} & \multicolumn{2}{|c|}{$\begin{array}{c}\text { Sample size necessary for } \overline{\mathrm{x}} \text { (final } \\
\text { infiltration rate after } 30 \text { minutes) } \\
\text { within one } \mathrm{cm} / \mathrm{hr} \text { of } \mu \text { with } \\
\text { confidence }\end{array}$} \\
\hline & & & & .80 & .90 & .80 & .90 \\
\hline Flats & unfenced & 3 & 6.35 & 35 & 58 & 8 & 14 \\
\hline Flats & fenced & 3 & 6.35 & 70 & 118 & 8 & 14 \\
\hline Flats & tilled & 9 & 6.35 & 1 & 2 & 1 & 1 \\
\hline Flats & tilled & 3 & 6.35 & 1 & 1 & 1 & 2 \\
\hline Flats & tilled & 3 & 12.7 & 1 & 2 & 4 & 6 \\
\hline Nancy & unfenced & 6 & 12.7 & 21 & 35 & 38 & 64 \\
\hline Nancy & fenced & 6 & 12.7 & 29 & 48 & 62 & 105 \\
\hline Nancy & tilled & 6 & 12.7 & 1 & 1 & 4 & 7 \\
\hline Lower Sheep & unfenced & 9 & 12.7 & 84 & 143 & 38 & 64 \\
\hline Lower Sheep & fenced & 9 & 12.7 & 59 & 100 & 11 & 19 \\
\hline Lower Sheep & tilled & 9 & 12.7 & 1 & 1 & 2 & 4 \\
\hline
\end{tabular}

Above values calculated using the formula $n=t^{2} s^{2} / d^{2}$ where $n=$ required sample size, $t=$ tabulated value for desired confidence and degrees of freedom of initial sample, $d=$ half width of desired confidence interval, $s=$ standard deviation of a given sample. 


\section{Methods}

All small plot infiltrometer data were collected using a modular drop-forming device (designed after one described by Chow and Harbough (1965) and modified by Meeuwig (1971) and further modified by Malekuti and Gifford (1978)). Rainfall simulation on small plots $\left(0.37 \mathrm{~m}^{2}\right)$ began with soils at field capacity (pre-wet by applying $9,440 \mathrm{cc}$ water to each small plot approximately 12 hours prior to the infiltrometer run), to eliminate confounding effects of any antecedent moisture.

Rainfall was applied for 30 minutes to each small plot (wet run). On the Flats site only, one-half hour after the wet run ended, simulated rainfall was again applied for one-half hour. This was called the very wet run.

Average rainfall application rates $( \pm 0.4 \mathrm{~cm} / \mathrm{hr})$ were either 6.35 $\mathrm{cm} / \mathrm{hr}$ or $12.7 \mathrm{~cm} / \mathrm{hr}$. The median drop diameter of the simulated rainfall was $2.9 \mathrm{~mm}$. Using data from Laws (1941), the kinetic energy associated with this simulator, when run at a height of 183 $\mathrm{cm}$, is about $40 \%$ that of natural rainfall.

The time to ponding (or time runoff begins) was defined as the time when measurable (i.e., approximately 10 to $15 \mathrm{ml}$ runoff in 15 seconds) runoff occurred from the small plot. Volume of runoff was recorded for 15 or 30 seconds (depending upon the volume) at the following times after runoff began: at 1 -minute intervals for the first 4 minutes, at 2-minute intervals for the next 6 minutes, and 5-minute intervals thereafter.

Small plots were located within large $(3.05 \mathrm{~m} \times 10.67 \mathrm{~m})$ rainfall simulator plots, which were part of a concurrent Agricultural Research Service (USDA) study. (Large plot data are not included in this analysis because, due to differences in instrumentation and routing on the large plot, large and small plot infiltration data are not comparable. This has been amply demonstrated by Smith (1979). Runoff from the large plot simply represents the response of a micro-watershed, in which the "rainfall excess" has been routed over the surface.) On large plots in either the fenced or unfenced condition, 20 small plots were sampled within each large plot. Ten small plots were systematically located within two randomly identified belt transects on each large plot. (Figure 7 illustrates the sampling design as described.) On large plots in a rototilled condition, 10 small plots, randomly located within each large plot, were sampled.

After obtaining runoff data from a small plot, surface soil characteristics were sampled. Two samples of soil (with a core diameter of $5.4 \mathrm{~cm}$ and core depths of $2.54 \mathrm{~cm}$ and $7.62 \mathrm{~cm}$ ) were taken for determination of bulk density $(\mathrm{g} / \mathrm{cc})$, particle size distribution (hydrometer method-Bouyoucos 1962) and soil organic matter (colorimetric analysis-Sims and Haby 1971).

Vegetal cover was measured with a point frame (Levy and Madden 1933). Fifty evenly spaced points were sampled on each small plot. Strikes from the first hit to the ground surface were recorded. Cover was classified as bare soil, litter, vegetal basal cover, and vegetal crown cover (by species). Rock was included in ground cover with small rock (2-6 mm diameter), gravel (6-20 $\mathrm{mm}$ diameter), medium rock (20-50 $\mathrm{mm}$ diameter), and large rock (greater than $50 \mathrm{~mm}$ diameter) recorded separately.

For each site, all small plot infiltration curves were used to investigate site variability.

\section{Results and Discussion}

Average, Maximum, and Minimum Infiltration Curves for Small Plots within a Given Large Runoff Plot

Figure 1 shows the average, maximum, and minimum infiltration curves on the tilled plots on the 3 sites. The curves were obtained by dividing the 30 - minute run into 2 -minute intervals, finding the average, maximum, and minimum infiltration rates over the given interval, and plotting these rates at the midpoint of each time interval.

Times where the infiltration capacity exceeded the rainfall inten-
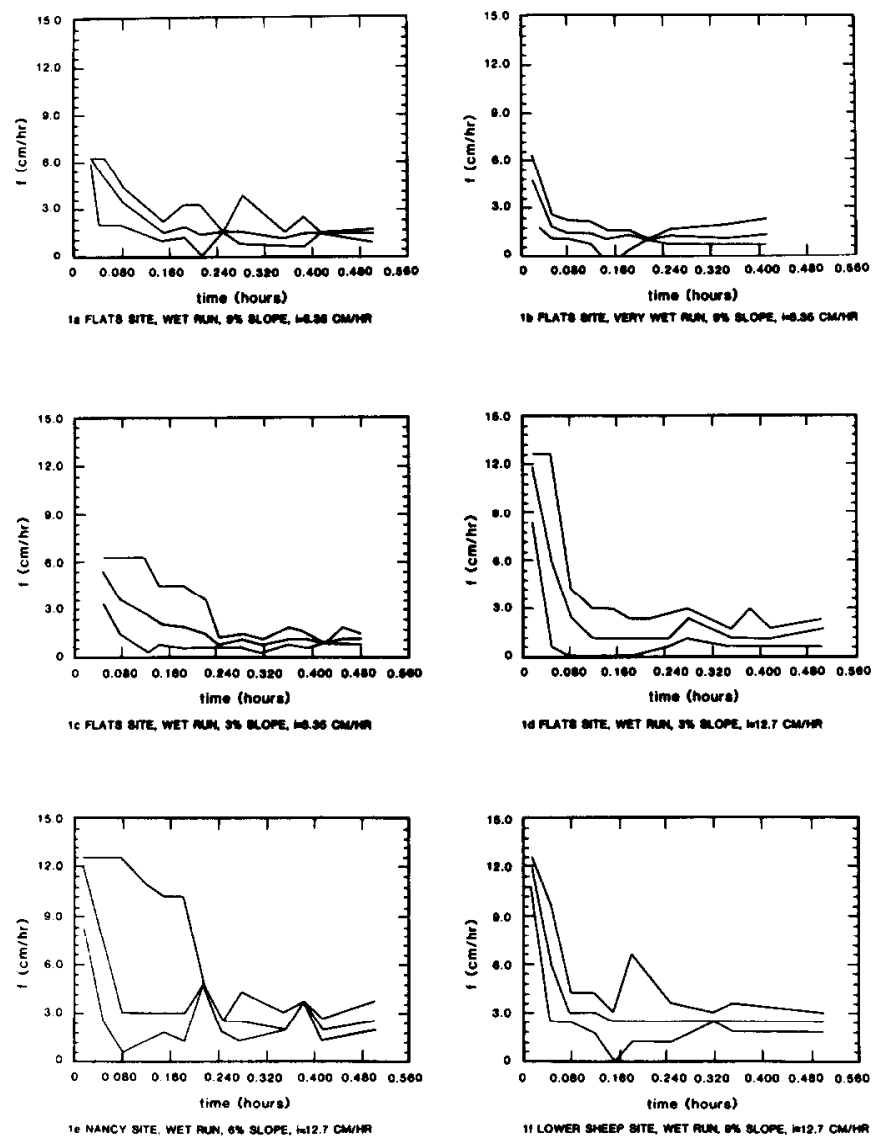

Fig. 1. Maximum, average, and minimum infiltration rates versus time for 10 small plots on large tilled plots (site, slope and rainfall intensity are given).

sity were not included in calculations of the average infiltration rate because the actual infiltration rate is not quantifiable for these points. This causes a downward bias of the maximum and average curves by an unknown amount.

Similar graphs (Fig. 2, 3) for the unfenced and fenced sites portray a much wider range of possible values. In some cases, even at a rainfall intensity of $12.7 \mathrm{~cm} / \mathrm{hr}$., the infiltration capacity exceeded the application rate for the duration of the 30-minute run (see Table 2).

The mean final infiltration rates are given in Table 2 . The mean final infiltration rates on fenced and unfenced plots are at least an order of magnitude greater than those on the tilled plot on the same site. Unlike on the tilled plot, the minimum curves on the fenced and unfenced plots approach values above zero. The minimum curves approximate the mean tilled plot curve, indicating that conditions giving the lowest infiltration rate on fenced and unfenced plots are similar to those responsible for average infiltration rates on a tilled plot.

The increases and decreases in infiltration rates as shown in average and minimum infiltration curves in Figure 1-3 were possibly due to air counterflow, inhomogeneity of the soil, other unquantified changes in soil characteristics with time, duration of the rainfall simulator runs, and instrument or sampling error.

\section{Individual Small Plot Characteristics: Lower Sheep Site as an Example}

Having examined general small plot curves, it is useful to examine specific small plot curves, and their variability. The Lower Sheep Site is used as an example; the variability patterns on this site are representative of the variability pattern found at all of the sites. Figures 4, 5, and 6 show the differences between individual small plot responses on rototilled, unfenced and fenced sites. Small 


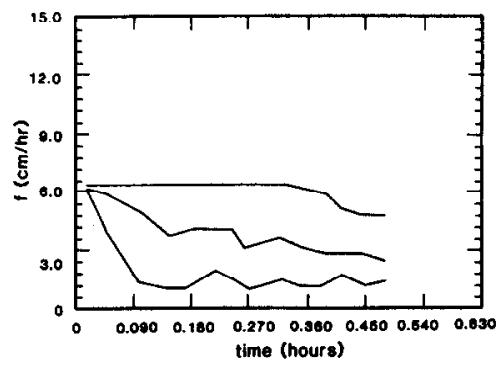

2a FLATS SITE, 3* SLOPE, $i=6.35 \mathrm{CM} / \mathrm{HR}$

16 of 20 SMALL SITES PLOTS RECEIVING RUNOFF

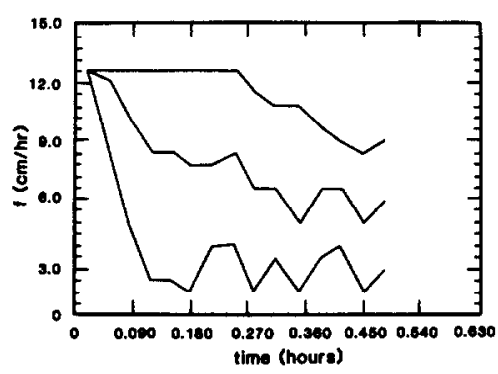

2b NANCY SITE, 6\% SLOPE, $i=12.7 \mathrm{CM} / \mathrm{HR}$

to of 20 SMALL SITES PLOTS RECEIVWG RUNOFF

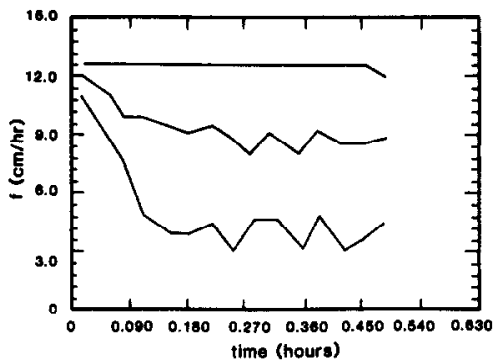

2c LOWER SHEEP SITE, 9\% SLOPE, $i=12.7 \mathrm{CM} / \mathrm{HR}$ 15 of 20 SMALL SITES PLOTS RECEIVING RUNOFF

Fig. 2. Maximum, average, and minimum infiltration rates versus time for the small plots where runoff occurred on each unfenced large plot (site, slope, and rainfall intensity are given).

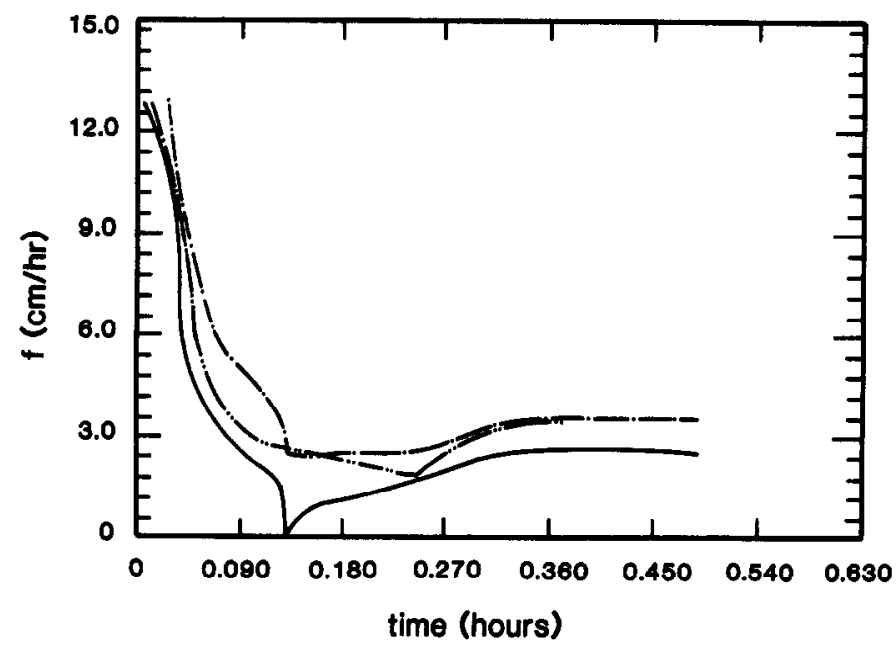

Fig. 4. Three of 10 individual infiltration curves (as examples) showing variability on the Lower Sheep tilled, $9 \%$ slope, large plot at the average rainfall intensity of $12.7 \mathrm{~cm} / \mathrm{hr}$.

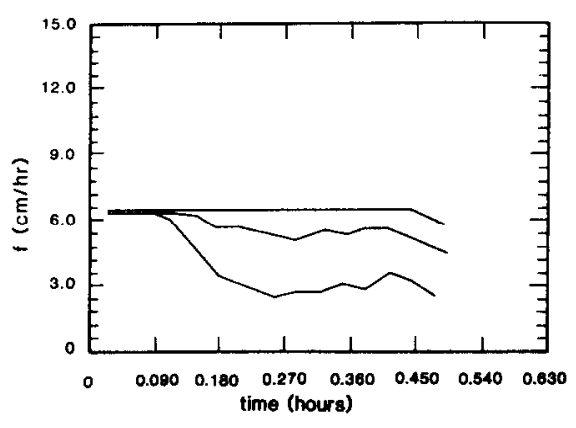

3A FLATS SITE, 3\% SLOPE, I=6.35 CM/HA 15 of 20 SMALL PLOTS RECEIVING RUNOFF

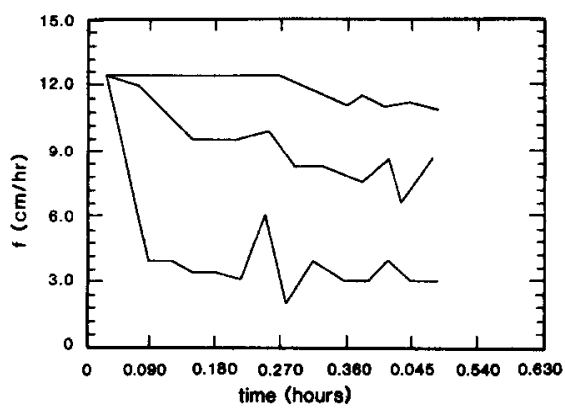

3b NANCY SITE, OW SLOPE, i=12.7 CM/HR

18 of 20 SMALL PLOTS RECEIYME RUMOFF

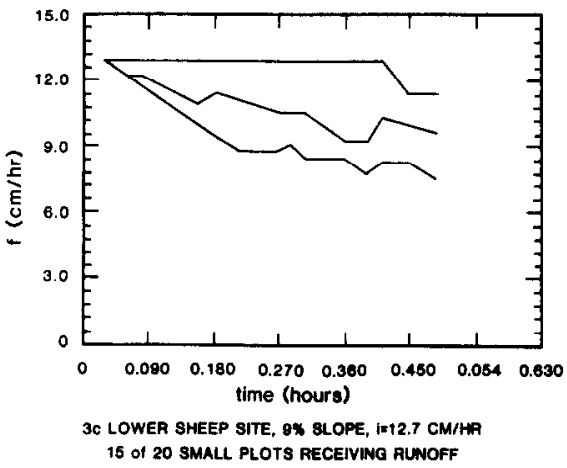

Fig. 3. Maximum, average and minimum infiltration rate versus time for the small plots where runoff occurred on each fenced large plot (site, slope, and rainfall intensity are given).

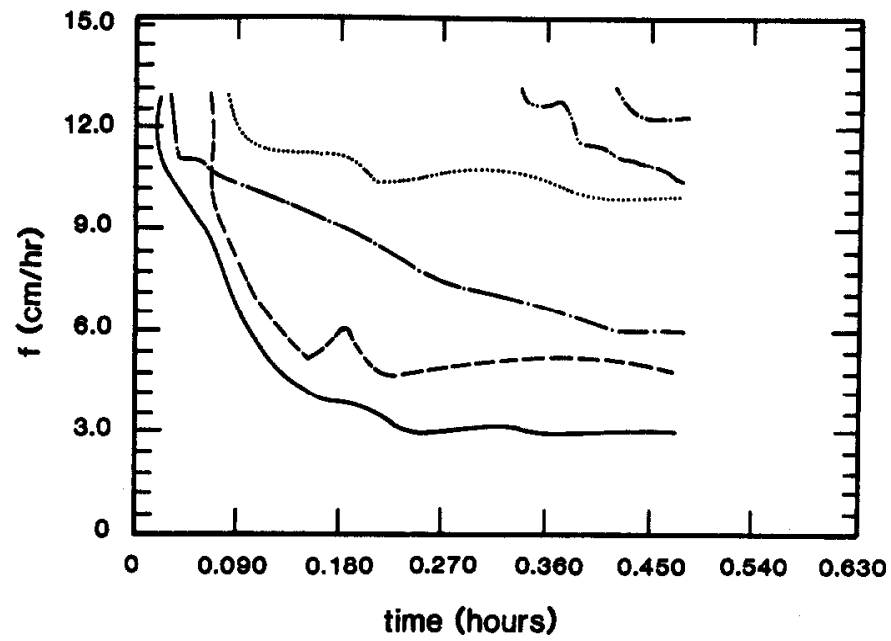

Fig. 5. Six 20 infiltration curves (as examples) showing variability on the Lower Sheep unfenced, $9 \%$ slope, large plot at the average rainfall intensity of $12.7 \mathrm{~cm} / \mathrm{hr}$. 


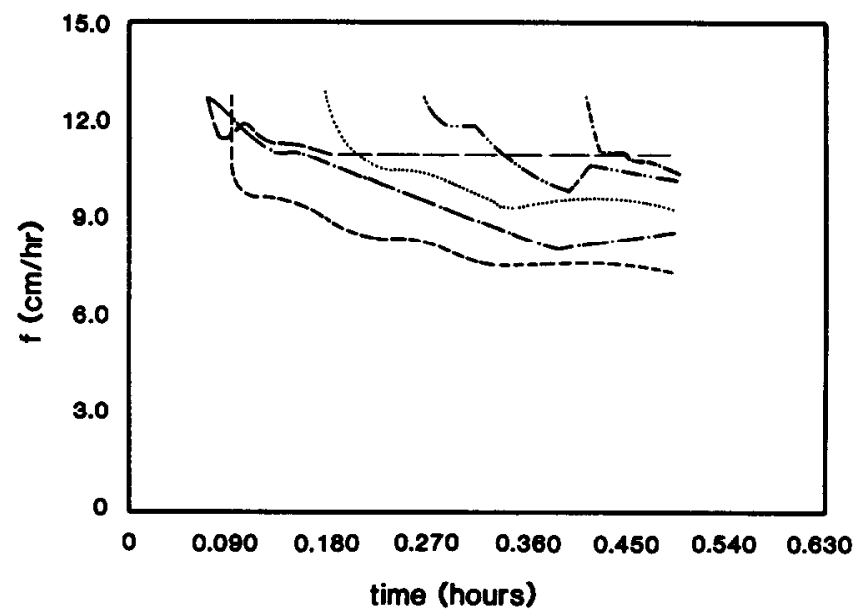

Fig. 6. Six of 20 infiltration curves (as examples) showing variability on the Lower Sheep fenced, $9 \%$ slope, large plot at the average rainfall intensity of $12.7 \mathrm{~cm} / \mathrm{hr}$.

plots where the infiltration capacity exceeded the rainfall intensity for the duration of the run are not included in Figures 5 and 6.

The relationship between small plot position on the slope and final 30-minute infiltration rate and vegetal cover is shown in Figures 7 and 8 . These figures show that plot positioning has no impact on 30-minute infiltration rates; vegetal cover and associated soil factors have the most influence on variability of infiltration.

Given this large variability in infiltration on a relatively homogeneous site, we looked at the ranges of other parameters that may be contributing to this variability. Figure 9 shows mean values for time to ponding and final infiltration rate. These graphs show mean values \pm standard deviations for unfenced, fenced and tilled

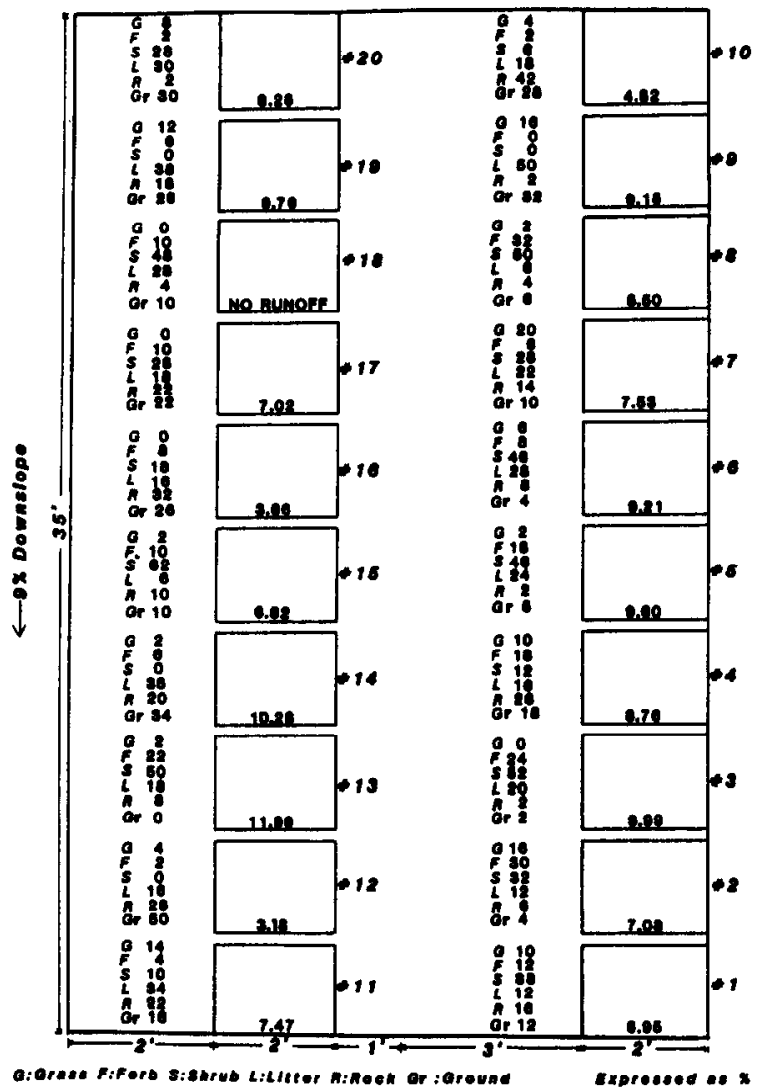

Fig. 7. Final 30-minute infiltration rates and vegetal cover relative to plot position on Lower Sheep unfenced site. (Ground $(G)$ category includes percent bare ground plus percent of soil surface covered by minute organic particles).

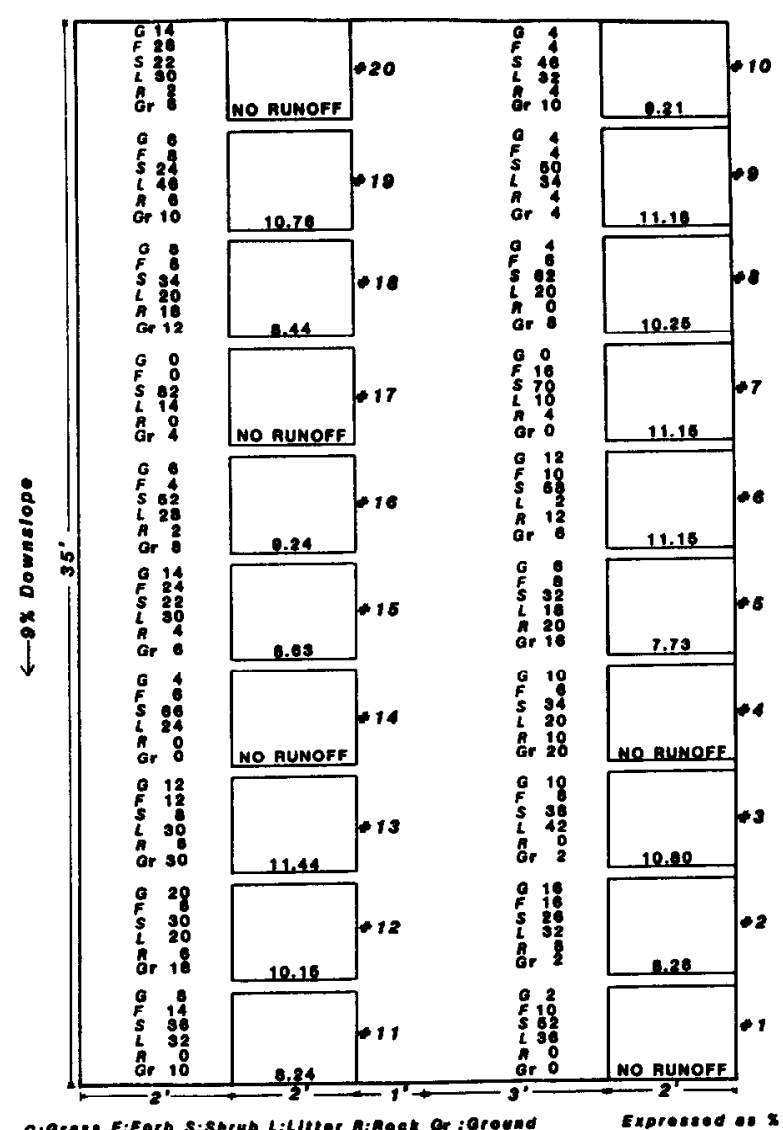

Fig. 3 Final 30-minute infiltration rates and vegetal cover relative to plot position on Lower Sheep fenced site. (Ground (Gr) category includes percent bare ground plus percent of soil surface covered by minute organic particles.)

plots on the Lower Sheep site. There was much greater variability of values on the unfenced and fenced plots than on the tilled plot. This same trend is also evident when looking at bulk density, percent organic matter, and soil texture. Figure 10 illustrates this trend for percent organic matter.

Differences between tilled and natural surfaces (i.e. unfenced and fenced) indicates that surface condition found on unfenced and fenced sites reflects either ( 1 ) the effects of tilling on creating a

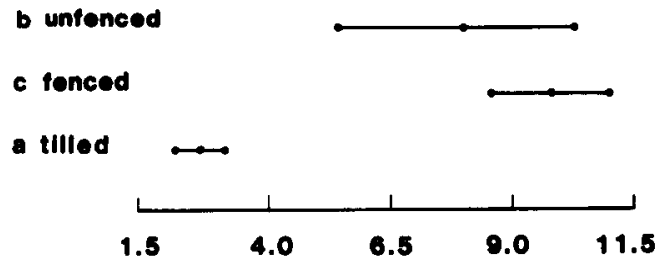

FINAL INFILTRATION RATE AFTER 30 MINUTES $(\mathrm{cm} / \mathrm{hr})$

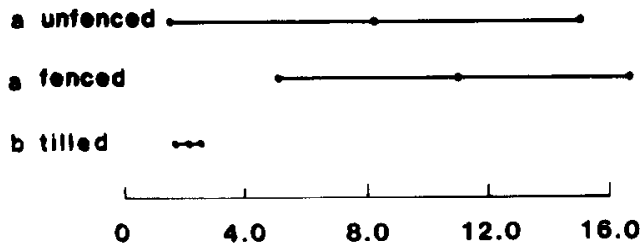

TIME TO PONDING (min)

Fig. 9. Mean \pm standard deviation for times to ponding and final infiltration rates for 3 treatments on the Lower Sheep, 9\% slope site at the rainfall intensity of $12.7 \mathrm{~cm} / \mathrm{hr}$. 


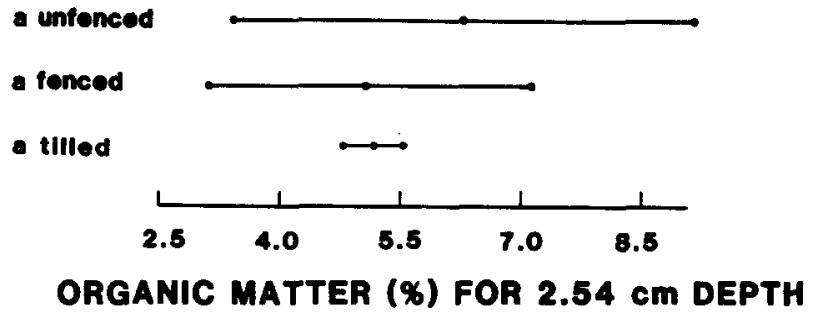

a unfenced $\longrightarrow$

e tenced

a tilled

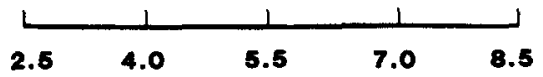

ORGANIC MATTER (\%) FOR $7.62 \mathrm{~cm}$ DEPTH

Fig. 10. Mean \pm standard deviation of percent organic matter for 2.54 and

$7.62 \mathrm{~cm}$ soil depths for 3 treatments on the Lower Sheep, $9 \%$ slope site.

homogeneous surface or (2) the effect of the diversity of vegetal cover (i.e., shrub, interspace, or bare ground), on soil surface characteristics.

Impact of Soil Properties and Vegetal Cover on Infiltration Rates

In an effort to explain site variability on the unfenced and fenced plots, rangeland soil properties and vegetal cover were correlated with hydrologic response (e.g., measured as final infiltration rate after 30 minutes). As has been found in previous studies (Blackburn 1973, Gifford 1972, Williams et al. 1972, and Busby and Gifford 1981), the correlations showed that no set of factors consistently explained small plot variability. Stepwise multiple regressions gave much the same results. Although $\mathrm{R}^{2}$ values indicate that on a given area it is possible to find a set of factors that accurately predicts the final infiltration rate (see Table 3), relationships between rangeland soil properties, vegetal cover, and infiltration change from area to area. Hence it would be difficult to select a set of factors that would consistently explain the observed variability from one area to another.

\section{Conclusions}

Given the large variability in measured infiltration and soil physical properties that we noted on relatively uniform rangeland sites, it is logical to ask how many samples are necessary to accurately define a site. As experienced in this study, it would take from 1 to 84 plots in order for the average time to ponding to be within 2 minutes of the real time to ponding (population value) with $80 \%$ confidence. Fewer samples are necessary to accurately define the average final (after 30 minutes) infiltration rate, as shown in Table 4. To be within $1 \mathrm{~cm} / \mathrm{hr}$ of the actual final infiltration rate, however, 4 times the number of plots shown in Table 4 would be needed. Due to the variability on any given area, single parameter values exhibit wide confidence intervals. Small-plot studies are useful in defining the confidence interval for a given parameter.

The large spatial variability of field-measured infiltration rates and associated soil parameters suggests that, if variability is of importance, extensive sampling will be necessary to define inherent variability patterns. Just how to incorporate such spatial variability into hydrologic models or into a practical land management approach is unclear; unless insights are available on this, it may be best to first ignore the problem of spatial variability and lump watershed characteristics as areal averages. If the variability of a given site is characterized, however, when average, effective, or fitted values are subsequently used in modeling watershed response, inaccuracies and biases in such assumptions will be better defined. On the other hand, lumped parameters may be sufficiently accurate in most cases when the costs of additional sampling are balanced against expected uses of the model output and the accuracy required.
The results of this study indicate a need for further investigation of variability on rangelands. First, the variability in infiltration on a homogeneous soil surface must be characterized for use as a baseline. Then studies very similar to the one described herein should be done on diverse rangeland sites. Eventually, such studies would enable a researcher to characterize the variability associated with an individual measurement or model parameter estimate for a given site.

\section{Literature Cited}

Achouri, M. 1982. Spatial and seasonal variability of field measured infiltration rates on rangelands. M.S. thesis, Utah State Univ., Logan.

Blackburn, W.H. 1973. Infiltration rate and sediment production of selected plant communities and soils in five rangelands in Nevada. Final Report for Contract No. 14-11-0001-4632. Agr. Exp. Sta. , Univ. Nevada Reno in cooperation with U.S. Dep. Interior, BLM.

Blackburn, W.H. 1975. Factors influencing infiltration and sediment production of semiarid rangelands in Nevada. Water Resour. Res. 11:929-937.

Bouyoucos, G.J. 1962. Hydrometer method improved for making particie size analyses of soil. Agron. J. 54:464-465.

Busby, F.E., and G.F. Gifford. 1981. Effects of livest tock grazing on infiltration and erosion rates measured on chained and unchained pinyonjuniper sites in southeastern Utah. J. Range Manage. 34:400-405.

Chow, V.T., and T.E. Harbough. 1965. Raindrop production for laboratory watershed experimentation. J. Geophys. Res. 70:6111-6120.

Cundy, T.W. 1982. An analysis of the effects of spatial variability of point infiltration rates on the comparison of small and large plot rainfallrunoff. Ph.D. Diss., Utah State Univ., Logan.

Gifford, G.F. 1972. Infiltration rate and sediment production trends on a plowed big sagebrush site. J. Range Manage. 25:53-55.

Gifford, G.F. 1976. Applicability of some infiltration formulae to rangeland infiltrometer data. J. Hydrol. 28:1-11.

Grah, 0.J. 1983. Spatial and temporal distribution of infiltration rates on a small subalpine watershed. M.S. thesis, Utah State Univ., Logan.

Hawkins, R.H. 1981. Interpretation of source area variability on rainfallrunoff relationships. Intern. Symp. on Rainfall-Runoff Modeling. Mississippi State Univ.

Laws, J.0. 1941. Measurements of the fall-velocity of water-drops and rain-drops, Trans. Amer. Geophys. Union, 22:709-721.

Levy, E.G., and E.A. Madden. 1933. The point method of pasture analysis. New Zealand J. Agr. 46:267-269.

Lyford, F.P., and H.K. Qashu. 1969. Infiltration rates as affected by desert vegetation. Water Resour. Res. 5:1373-1376.

Malekuti, A., and G.F. Gifford. 1978. Natural vegetation as a source of diffuse salt within the Colorado River Basin. Water Resour. Bull. 14:195-205.

Meeuwig, R.o. 1971. Infiltration and water repellancy in granitic soils. U.S. Forest Serv. Res. Paper INT-111.

Merzougui, M.1982. The effect of instrument type in measuring infiltration rates on spatial variability patterns. M.S. thesis, Utah State Univ., Logan.

Murabayashi, E.T., and Yu-Si Fok. 1979. Urbanization-induced impacts on infiltration capacity and on rainfall-runoff in a Hawaiian urban area. Tech. Rep. No. 27, Water Resour. Res. Center, Honolulu, Hawaii.

Rogowski, A.S. 1980. Hydrologic parameter distribution on a mine spoil. p. 764-780. In: Symposium on Watershed Management (Proc.). Amer. Soc. Civil Engineers, New York.

Sharma, M.L., G.A. Gander, and C.G. Hunt. 1980. Spatial variability of infiltration in a watershed. J. Hydrol.. 45:101-122.

Sims, J.R., and V.A. Haby. 1971. Simplified colorimetric determination of soil organic matter. Soil Sci. 112:137-141.

Smith, R.E. 1979. Rainfall simulation as a research tool-simulation for infiltration studies. In:Proc. Rainfall Simulator Workshop, Tucson, Ariz. ARM-W-10:78-84.

Smith, R.E., and R.H.B. Hebbert. 1979. A Monte Carlo analysis of the hydrologic effects of spatial variability of infiltration. Water Resour. Res. 15:419-429.

Springer, E.P., and G.F. Gifford. 1980. Spatial variability of rangeland infiltration rates. Water Resour. Bull. 16:550-552.

Stephenson, G.R. 1977. Soil-geology-vegetation inventories for Reynolds Creek Watershed. Agr. Exp. Sta., Univ. of Idaho. Misc. Series No. 42.

Tricker, A.S. 1981. Spatial and temporal patterns of infiltration. J. Hydrology 49:261-277.

Vieira, S.R., D.R. Nielsen, and J.W. Bigger. 1981. Spatial variability of field-measured infiltration rate. Soil Sci. Soc. Amer. J. 45:1040-1048.

Williams, G., Gifford, G.F., and G.B. Coltharp. 1972. Factors influencing infiltration and erosion on chained pinyon-juniper sites in Utah. J. Range Manage. 25:201-205. 